J. Product. \& Dev., 25(1): 79-99 (2020)

\title{
GENETIC DIVERSITY AND RELATIONSHIPS AMONG GRAPEVINE ROOTSTOCK MUTANTS THROUGH RAPD TECHNIQUE
}

\author{
M. A. Zayan ${ }^{1}$; A. R. El-Shereif ${ }^{1}$; Aisha S. A. Gaser ${ }^{2}$ and Asmaa M. Salama ${ }^{2}$ \\ 1-Pomology Department, Faculty of Agriculture, Kafrelsheikh \\ University, Egypt. \\ 2- Viticulture Research Department, Horticulture Res. Inst., Agric. Res. \\ Center, Giza, Egypt.e.mail:asmaa_mohi@yahoo.com
}

\section{ABSTRACT}

Mutation using radiation has been shown to be an important tool in incorporating specific desirable agronomic value characteristics. In the present study, four grapevine rootstocks namely: Freedom, Harmony, SO4 and Ramsey along with commercial variety Thompson seedless were exposed to different doses of gamma rays $(0,10,20 \mathrm{~Gy})$ to obtain mutations with economic values.

Results showed that both doses of 10 and 20 Gy were effective in obtaining mutations in all grapevine genotypes including Thompson seedless, which were confirmed by morphological markers such as bud burst percentage and shoot length and number of leaves, and genetic markers by RAPD technique.

In addition, genetic variation and relationships in both irradiated and un-irradiated genotypes were determined. Six RAPD markers were able to generate polymorphic bands ranged from 1 to 9 among irradiated and un-irradiated grapevine genotypes. The similarity coefficients detected by RAPD markers ranged from 0.24 to 0.87 , which revealed clear genetic variation among irradiated and un-irradiated grapevine genotypes. According to phylogenetic analysis, genotypes were divided into two clusters, where all five un-irradiated genotypes and irradiated Freedom genotype with 10 Gy were placed in one cluster and second cluster included the rest of nine irradiated genotypes.

Conclusively, this study supports the use of mutation in breeding grapevine improvement, and RAPD technique could be an important tool for detecting mutations and genetic diversity among grapevine genotypes.

Key words: Mutation, grapevine varieties, RAPD technique, rootstocks

\section{INTRODUCTION}


Grapes (Vitis vinifera L.) belong to the family Vitaceae, and rank first among fruit crops in the world in terms of the production and economic importance (Vivier and Pretorius, 2002). Grapes areas have recently increased rapidly in Egypt and reached about 77895 Hektar, which produced about 1703394 tons in 2017 season (FAO, 2017). Mutation breeding is one of the oldest breeding programs. Natural mutations and traditional breeding methods have been used to develop new genotypes that are superior with respect to some agronomic characteristics, high quality and more resistant to biotic and abiotic stress. Since natural mutations appear spontaneously, and are not so easily detectable, so many researchers have used artificial mutations in different plant varieties to induce genetic variations, which are easier, cheaper and more variable (Donini, 1993).

Selection of appropriate genotypes from positive or negative variations occurred by different mutagen doses is the main principle of mutation breeding. In general, vegetative and generative parts of plants such as cutting, tuber, stem, seed etc. are used in mutation applications. Breeding mutations program has become more common and widespread among plant breeders in particularly with the limitations of some biotechnologies in Egypt such as wide hybridizations and genetically modified plants. It is of great importance in determination of suitable mutagen doses, which have lower physiological damage and enable to provide us higher genetic effect and variations (Klu and Haarlent, 2000).

Nowadays, the number of cultivars derived from mutation induction increases constantly (Hearn, 2001). Inducing mutations by gamma rays has been effectively used with several species. Irradiation of gamma rays on bud wood can produce higher frequencies of mutation leading to the creation of new genetic recombinations. Random Amplified Polymorphic DNA (RAPD) markers are suitable to perform with good polymorphism and can be used in examining genetic diversity and the relation between species at molecular level (Lanying et al. 2008, Arya et al. 2010). It consists of fragments having 10 nucleotides in length which are amplified through PCR of random segments of genomic DNA with one primer of random nucleotide sequence. RAPDs have been used consistently as molecular markers for classification of different grapes cultivars (Buscher et al., 1993).

Therefore, this study was aimed to induce mutations by gamma radiation in different grapevine genotypes, and to detect genetic diversity and relationships among mutants produced through RAPD technique for development of pre-breeding abiotic-tolerant grapevine genotypes which could be used as rootstocks in Egypt.

\section{MATERIALS AND METHODS}


The present study was conducted during two consecutive experimental seasons (2015 and 2016) at the experimental farm of Faculty of Agriculture, Kafrelsheikh University, Egypt.

\section{1- Plant materials}

Four grapevine rootstocks were used in the present study namely: Freedom (1613C x V. champini), Harmony (1613C x V.s champini), SO4 (V. berlandieri $\mathrm{x} V$. riparia), Ramsey ( $V$. candicans $\times$ V . rupestris), and grapevine cultivar "Thompson seedless" (V. vinifera $\mathrm{L}$.). These genotypes were obtained from El-Roda farm located at Beheira Governorate.

\section{2- Gamma irradiation doses and data recorded}

Forty-five cuttings from each selected grape rootstock along with grapevine variety "Thompson seedless" were cut and collected on the 31th of January 2015 and 2016. The selected cuttings with three buds/cutting and length at $20 \mathrm{~cm}$ were irradiated with five doses of gamma rays $0,10,20,30$ and $50 \mathrm{~Gy}$. Gamma rays were generated using cobalt 60 as a source of gamma rays. Irradiation of the cuttings was carried out at the National Center for Radiation Res. and Tech., Nasr City, Cairo, Egypt.

In the first week of February in both seasons (2015 and 2016), the irradiated cuttings were individually planted in plastic pots $(35 \mathrm{~cm}$. in diameter) each filled with approximately $6 \mathrm{Kg}$ of soil mixture from clay and sand (1:1 $\mathrm{v} / \mathrm{v})$. The cuttings in the pots were irrigated with tap water weekly at the rate of one liter/pot till the investigate treatments started on the 1st April of 2015 and 2016. All pots were supplied with a complex N, P, K Fertilizers (1:1:1) as well as $\mathrm{Fe}, \mathrm{Mn}$ and $\mathrm{Zn}$ micro elements in chelated form.

\section{The following data was recorded}

\section{1- Vegetative growth traits}

Vegetative growth traits were measured on irradiated cuttings of grapevine rootstocks and Thompson seedless as described below.

A- Bud burst percentage (opening bud \%): Number of bud burst, was calculated according to Huglin (1958).

$$
\text { Bud burst } \%=\frac{\text { No. of bursted buds/vine }}{\text { Total buds/vine }} \times 100
$$

B- Shoot length: Average shoot length $(\mathrm{cm})$ was measured by ruler

C- Number of leaves/plant: All new leaves developed on these shoots were counted.

D- Survival percentage: it was calculated using the following formula. 
Survival $\%=\frac{\text { Total No. of cuttings }- \text { Total No. of obening cuttings }}{\text { Total No. of cuttings }} \times 100$

\section{RAPD analysis}

RAPD analysis was carried out in Genetic Engineering and Tissue Culture Laboratory (GETCL) at faculty of Agriculture, Kafrelsheikh University. PCR analysis was carried out on five grape genotypes (unirradiated "control" and irradiated cuttings at two doses 10 and $20 \mathrm{~Gy}$, since the dose 30 Gy was not available for DNA isolation.

\section{A- DNA isolation}

DNA was isolated using CTAB method from fresh leaves of five grapes rootstocks and their radiated with doses 10 and 20 Gy according to Doyle and Doyle (1990). Fresh 100-150 mg of young leaves was collected and powdered under liquid nitrogen using mortar and pestle. The ground material was transferred into Eppendorf tubes. The $800 \mu \mathrm{l}$ of CTAB extraction buffer were added followed by vortexing. The tubes were incubated for $30 \mathrm{~min}$. at $60^{\circ} \mathrm{C}$. After incubation, $800 \mu \mathrm{l} \mathrm{CI-mix} \mathrm{were} \mathrm{added} \mathrm{and} \mathrm{tubes} \mathrm{were} \mathrm{gently} \mathrm{mixed} \mathrm{by}$ inverting the tube 4-5 times to avoid shearing of genomic DNA. The mixture was centrifuged at room temperature for $10 \mathrm{~min}$. at $12000 \mathrm{rpm}$. The aqueous phase (app. $800 \mu \mathrm{l}$ ) was transferred into a fresh $1.5 \mathrm{ml}$ Eppendorf tube. The centrifugation step was repeated to get a clear sample. About $550 \mu \mathrm{l}$ of precooled isopropanol were added. The tubes were centrifuged for $10 \mathrm{~min}$. at $14000 \mathrm{rpm}$ to precipitate the genomic DNA. The supernatant was discarded and the DNA pellet was washed with $200 \mu \mathrm{l}$ washing buffer until the pellet floats. Washing buffer was carefully removed and the pellet was resuspended in 200 $\mu 1$ TE buffer (10 mM Tris-HCl, $1 \mathrm{mM}$ EDTA, pH 8.0) supplemented with RNase A $(10 \mu \mathrm{g} / \mathrm{ml})$. The sample was incubated for $30 \mathrm{~min}$. at $37^{\circ} \mathrm{C} .100 \mu \mathrm{l}$ of $7.5 \mathrm{M}$ NH4-acetate and $750 \mu$ labsolute ethanol were added and gently mixed. The mixture was centrifuged at maximum speed for $10 \mathrm{~min}$. at roomtemperature. The supernatant was discarded completely and the pellet was dried for $40-50 \mathrm{~min}$. at $37^{\circ} \mathrm{C}$. After drying, the pellet was re-suspended in 100 $\mu 1$ TE buffer. DNA concentration and purity was assessed using Nanodropspectrophotometer (IMPLN Germany).

The isolated DNA samples were amplified using Taq DNA Polymerase 2x-preMix kit following the manufacturer protocol (GeneON, \# S113 and Taq DNA Polymerase 2X-preMix) and PCR Techne (TC-3000, USA). Eight multiplexing sets of RAPD primers were used in this study (Table 1). The PCR reactions were optimized and mixtures were prepared (in total volume of $25 \mu \mathrm{l}$ ). 
Table (1): List of multiplexing sets of the used RAPD primers in the present study

\begin{tabular}{|c|c|c|}
\hline No. & Primer name & primer seq.. \\
\hline 1 & OPA-04 & AATCGGGCTG \\
\hline 2 & OPA-05 & AGGGGTCTTG \\
\hline 3 & OPA-06 & GGTCCCTGAC \\
\hline 4 & OPA-10 & GTGATCGCAG \\
\hline 5 & OPA-11 & CAATCGCCGT \\
\hline 6 & OPA-12 & TCGGCGATAG \\
\hline 7 & OPA-13 & CAGCACCCAC \\
\hline 8 & OPA-14 & TCTGTGCTGG \\
\hline
\end{tabular}

PCR cycling was carried out as the following program, one cycle at 95 ${ }^{\circ} \mathrm{C}$ for 5 min., and then 35 cycles were performed as follows: $1 \mathrm{~min}$. at $95{ }^{\circ} \mathrm{C}$ for denaturation, $1 \mathrm{~min}$. at $36^{\circ} \mathrm{C}$ for annealing and $1.30 \mathrm{~min}$. at $72{ }^{\circ} \mathrm{C}$ for extension.

Reaction was incubated at $72^{\circ} \mathrm{C}$ for $7 \mathrm{~min}$. and then kept at $4{ }^{\circ} \mathrm{C}$. The loading buffer $(5 \mu \mathrm{l})$ was added to each sample of PCR product $(15 \mu \mathrm{l})$.

PCR products were separated by electrophoresis using $1 \%$ agarose gel in $0.5 \mathrm{x}$ TBE buffer against $100 \mathrm{bp}$ DNA Ladder as a size marker. Bands were detected with ethidium bromide staining and documented on Gel Documentation UVITEC, UK.

The run was performed for one hour at 80 volts in Bio-Rad submarine ( 8 $\mathrm{cm} \times 12 \mathrm{~cm}$ ). Agarose Gel electrophoresis was used to detect DNA fragments according to (Buitkamp et al., 1991) to determine the size of the PCR products.

\section{3- Statistical analysis}

All data about vegetative growth and molecular analysis were expressed as means. The statistical significance was evaluated by one-way analysis of variance (ANOVA) using SPSS, 18.0 software (SPSS, 2011).

The individual comparisons were obtained by Duncan's multiple range test (DMRT). Values were considered statistically significant when $\mathrm{P}<0.05$.

\section{RESULTS AND DISCUSSION}

\section{1- Vegetative growth}

\section{A. Opening buds (\%)}

The results presented in Tables (2 and 3) showed that percentage of opening buds was increased significantly with unirradiated Thompson seedless 
variety (control) and Thompson seedless irradiated with 10 Gy of gamma rays. Meanwhile the lowest percentage was observed in Freedom variety with 20 Gy at all sampling dates during 2015 and 2016 seasons. Thompson seedless cultivar recorded the highest percentage of opening bud followed by So4, Ramsey, Harmony and Freedom in both seasons.

The highest opening buds \% obtained by the control treatment (9.33 and $9.60 \%$ ) followed by genotypes irradiated with gamma rays at 10 Gy and the lowest values was observed with genotypes irradiated with dose 20Gy (5.07 and $5.27 \%$ ) in the two seasons respectively. These results suggest that gamma rays with high doses cause growth inhibition of buds which might be ascribed to the cell cycle arrest during somatic cell division and /or various damages in the entire genome (Preussa and Britta, 2003), also the reduction may be due to high content of ABA (Rabie et al., 1996), destructions or damage of apical meristem or reduction in the level of amylase activity and to temporary suspension of cell division or delay in mitosis or increase in the production of active radicals (Esmault et al., 2010). These results are in agreement with those obtained by previous studies (Coban et al., 2002, Tayyer et al., 2003, Dardeniz and Tayyer.,2005).

\section{B. Shoot length (cm)}

There was significant difference in the shoot length between the combination treatments in both seasons (Tables 4 and 5). As the growth progressed, the maximum shoot length was obtained with un-irradiated Thompson seedless and genotypes irradiated with $10 \mathrm{~Gy}$. Conversely, the lowest length of shoot was recorded with the combined treatments of Freedom x 20 Gy at all sampling dates during 2015 and 2016 seasons.

The highest shoot length recorded by Thompson seedless cultivar (Tables 4 and 5). Regarding to the effect of gamma ray doses, there were no significant differences among all doses of gamma rays in both seasons. The results obtained in the present investigation are similar to those of (Saiful et al.,2015, Tayyer et al.,2003, Dardeniz et al.,2005, Surakshitha et al.,2017).

\section{Number of leaves}

The combined treatments of Thompson seedless with no irradiation and Thompson seedless irradiated with 10 Gy gave the highest number of leaves as compared with the lowest number obtained by the combined treatments of Freedom with no irradiation, Freedom x 10 Gy and Freedom x 20Gy in the first season (Table 6). 
J. Product. \& Dev., 25(1):,(2020)

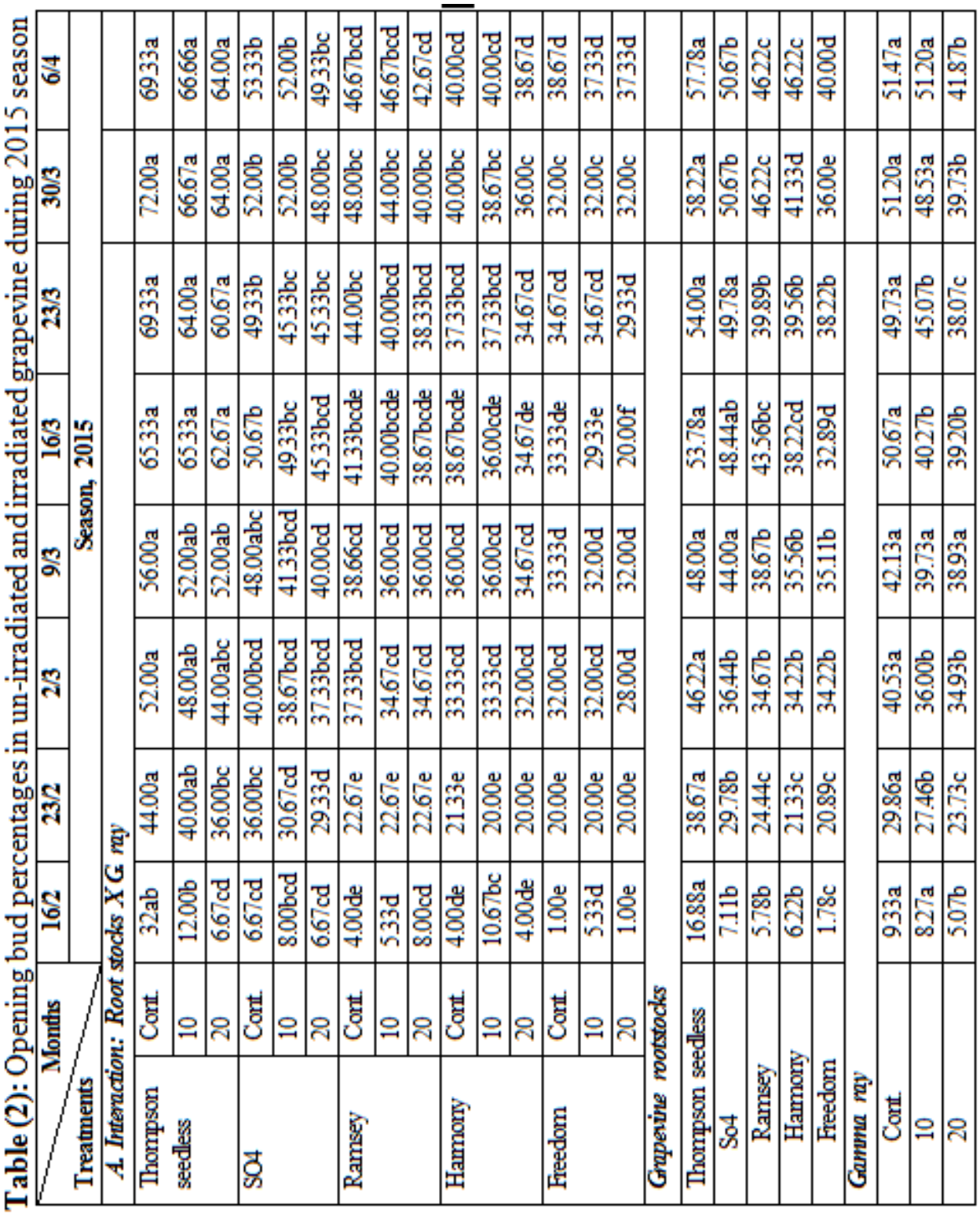




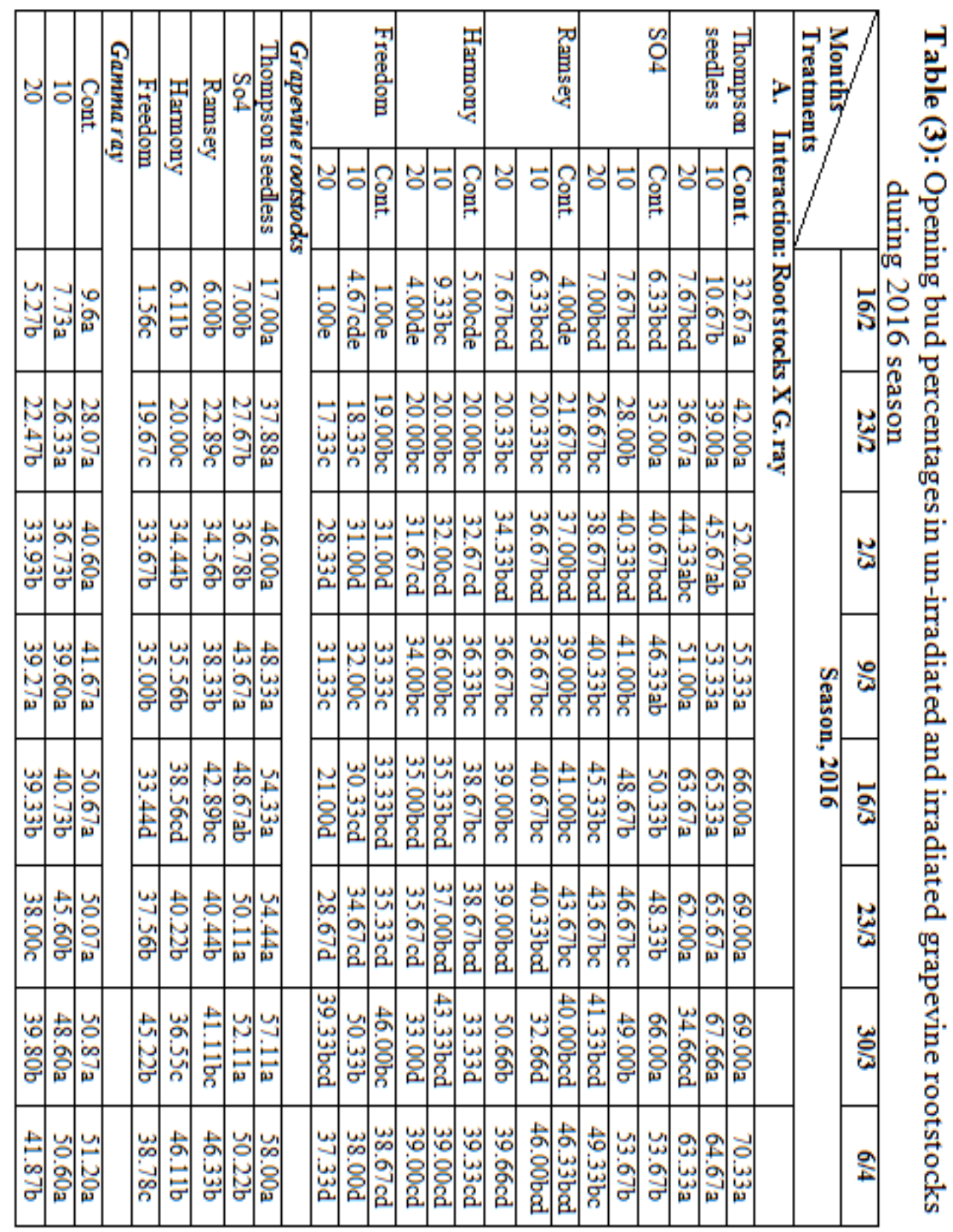









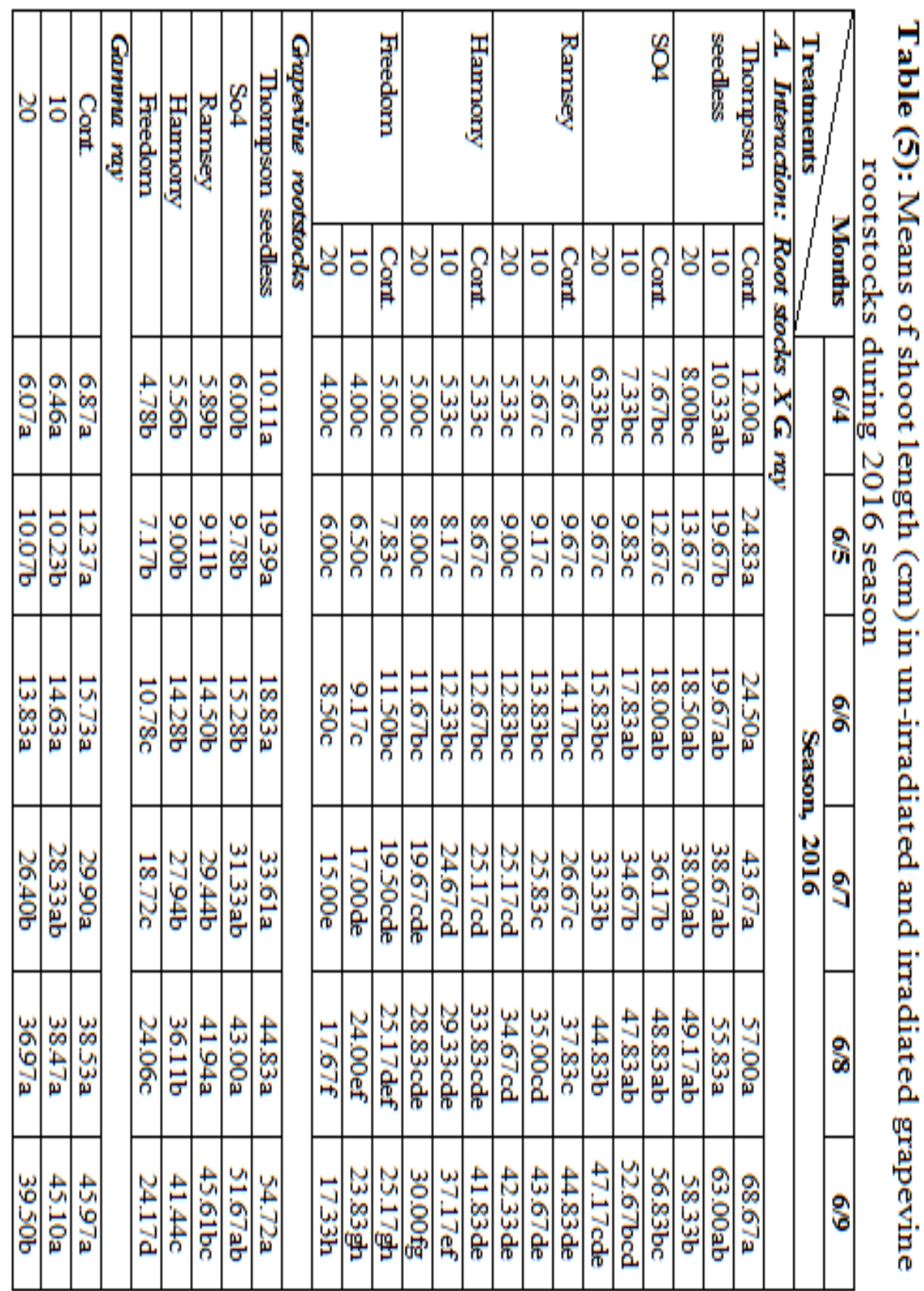


In the second season, the following combined treatments: Thompson seedless $\mathrm{x}$ 0 Gy and Ramsey x 10Gy were markedly increased the number of leaves compared with the lowest values obtained by the combined treatment of Thompson seedless x 20 Gy (Table 7). With respect to the effect of grapevine cultivars, data tabulated in Tables (6 and 7) showed that, Thompson seedless and So4 cultivars significantly increased number of leaves and Freedom cultivar produced the lowest number of leaves.

The highest number of leaves was recorded by control (0Gy) and 10Gy of gamma radiation compared with the lowest values recorded by the highest doses of gamma ray (20Gy) in the first season. In the second season, the differences were not significant at all sampling dates except at $6 / 5$ and 6/7. The highest number of leaves obtained under control treatment (0Gy) and 10 Gy dose of gamma ray, and gamma ray with $20 \mathrm{~Gy}$ resulted the lowest values.

Generally, growth inhibition might be induced by high doses of irradiation and this could be due to cell cycle arrest during somatic cell division and/or to a variety of damages in the entire genome (Shah et al., 2008). Processes like auxin destruction, changes of the ascorbic acid contents, and physiological and biochemical disturbances could also induce the inhibition of plant germination and development (Preussa and Britta, 2003). The frequency of chromosomal damage with increasing doses may be responsible for reduction in plant survival and development (Kiong et al., 2008). Similar trend has also been reported by Tayyer et al., (2003), Dardeniz et al., (2005), and Saiful et al. (2015).

\section{Survival rate (\%)}

The results illustrated in Figure (1) showed that the highest percentage of plant survival recorded with Thompson seedless received no irradiation and genotypes irradiated with $10 \mathrm{~Gy}$. Concerning to genotypes, the highest survival percentage obtained with Thompson seedless cultivars followed by So4, Freedom, Ramsey and Harmony in both seasons.

The reduction in survival percentage could be due to negative effects of irradiation which increases the formation of Reactive oxygen species (ROS) in plant cell causes damages in cellular homeostasis and progressive oxidative damage and finally cell death (Beyaz and Yildiz, 2016).

\section{2- Genetic diversity and relationships by RAPD analysis}

Eight Random Amplified Polymorphic DNA (RAPD) markers were used in the present study to detect mutations induced by gamma irradiation, and to investigate genetic diversity and relationships among four grapevine rootstocks 


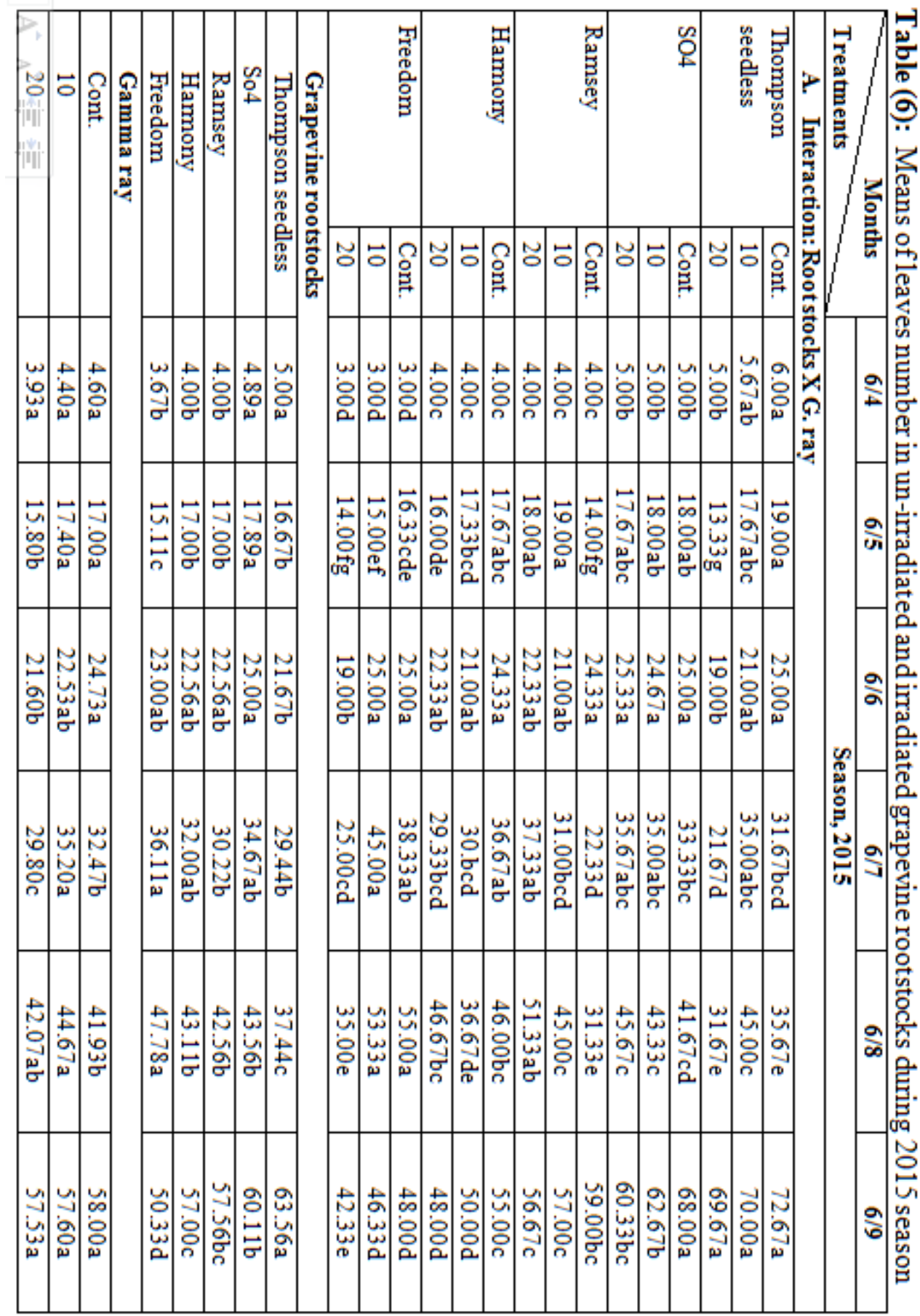




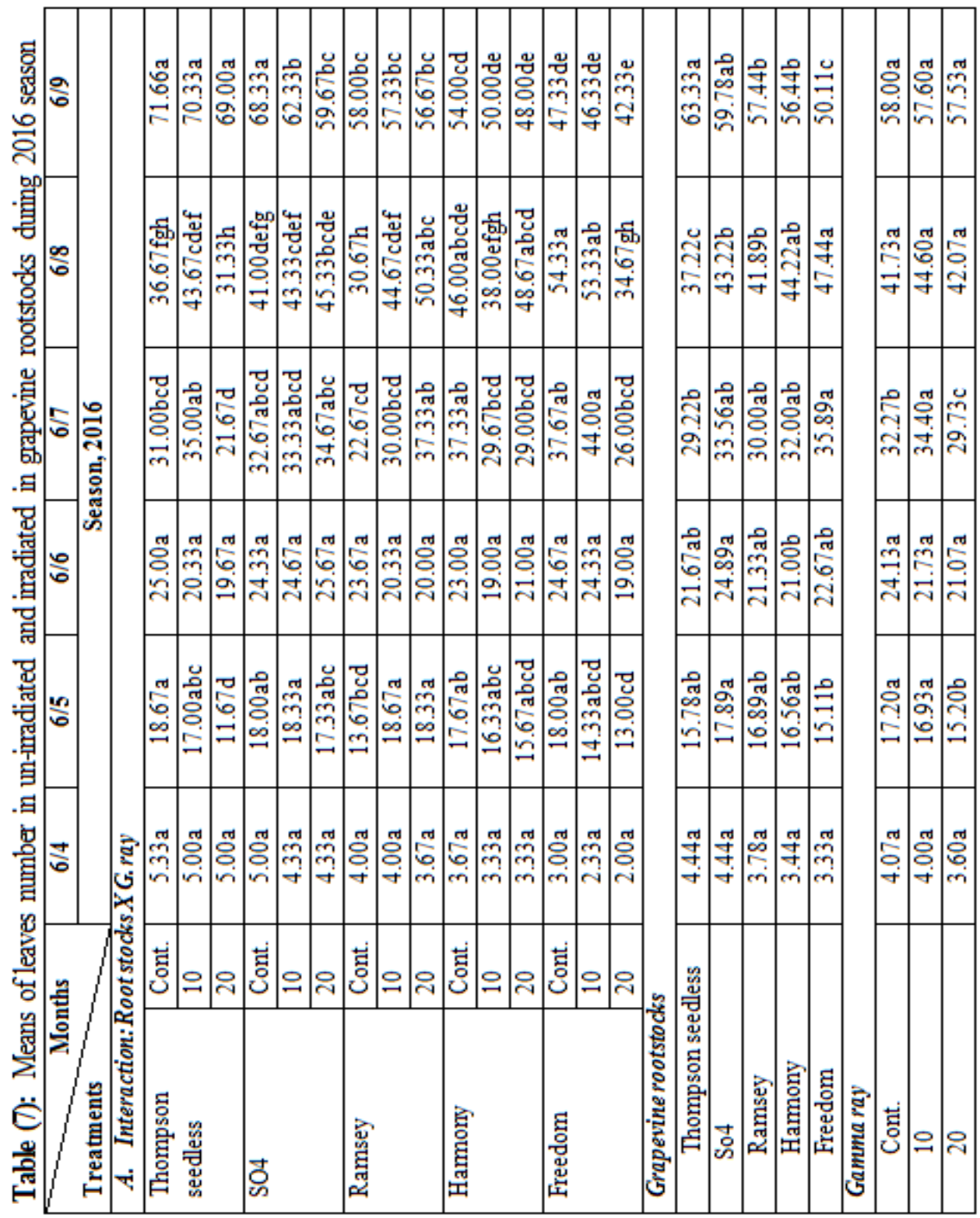




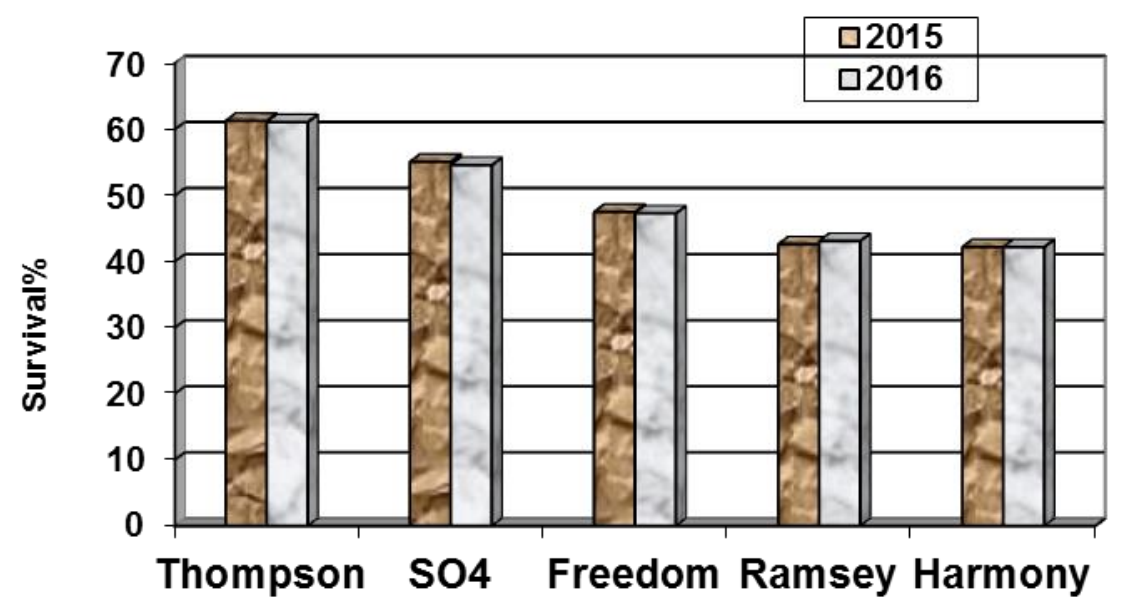

\section{Rootstocks}

Figure (1): Survival percentage as affected by irradiated grape vine rootstocks during 2015 and 2016 seasons.

and commercial variety Thompson seedless (Table 8 and Figure 2). Among eight RAPD primers, six primers were generated polymorphic bands. No bands were detected by the primers OPA- 6 and OPA- 13 across the irradiated and unirradiated grapevine genotypes. The total number of bands generated per primer varied from 1 to 9 .

The primer OPA-10 in SO4 genotype showed the lowest number of bands, while the highest numbers of bands were scored in Harmony genotype using the same primer (OPA-10). Although there were no accession-specific markers used in the present study, the high level of polymorphism suggests that RAPD markers could be considered a useful tool for detecting genetic diversity among different grapevine genotypes.

In general, total and polymorphic bands were higher in un-irradiated genotypes followed by genotypes irradiated with $10 \mathrm{~Gy}$. The numbers of polymorphic bands were ranged from 1 to 9,1 to 7 and 0 to 5 in un-irradiated genotypes, and irradiated genotypes with $10 \mathrm{~Gy}$ and $20 \mathrm{~Gy}$, respectively. The highest numbers of polymorphic bands were observed in OPA-10 in both irradiated and non-irradiated genotypes where all bands generated by this primer were polymorphic. The genetic similarity based on six RAPD primers ranged from 0.24 to 0.87 (Table 8 ). The highest genetic similarity $87 \%$ was found between unirradiated genotypes Harmony and Ramsey, on the other 


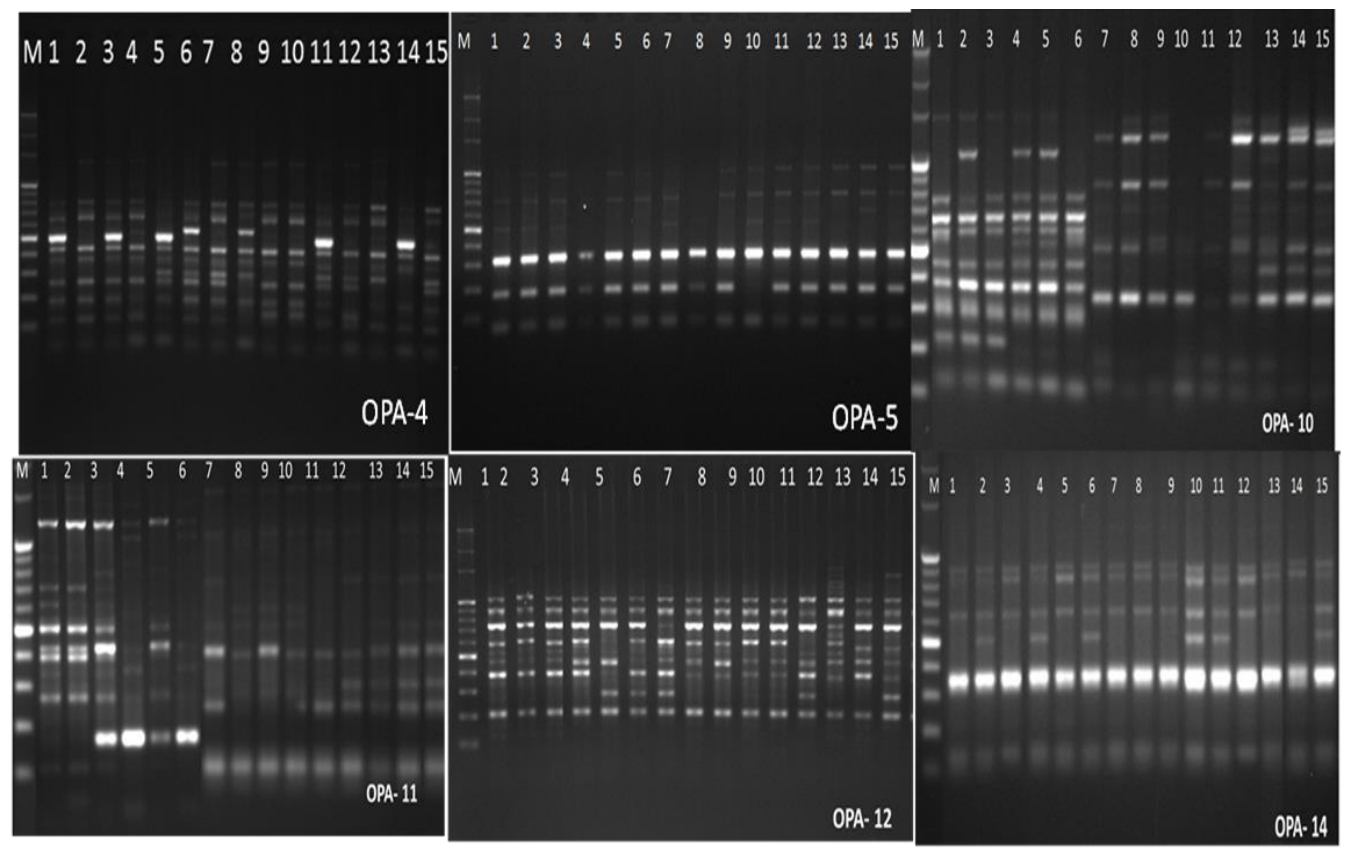

Figure (2). Survey of RAPD markers selected to detect induced mutation in Freedom, Harmony Ramsey, Thompson Seedless and So4 for primers (OPA-04, OPA-05,OPA-10,OPA-11,OPA-12,OPA-

hand, the lowest genetic similarity $24 \%$ was found between irradiated and unirradiated Thompson seedless genotype. The obtained results in Table 8 showed that the similarity indices were increased as the dose of gamma rays were increased in most of grapevine genotypes. Previous studies have also been shown RAPD markers to be efficient in distinguishing between grapevine rootstocks, and advantageous since it is cheaper and easier to perform than RFLP analysis or isoenzyme characterization.

The dendrogram (Figure 3) indicated two main clusters, one comprising un-irradiated five genotypes (Freedom, Harmony, SO4, Ramsey, and Thompson seedless) and irradiated Freedom with 10 Gy, while the second cluster included the rest of irradiated genotypes indicating their higher genetic distinctness between irradiated and un-irradiated genotypes. According to the dendrogram obtained, irradiated genotypes Freedom with 20 Gy and Harmony with 10 Gy were more distant compared to un-irradiated genotypes. In addition, results showed that un-irradiated So4 and Freedom genotype with 10 Gy were the closest from Thompson seedless variety in un-irradiated and irradiated genotypes, respectively. 


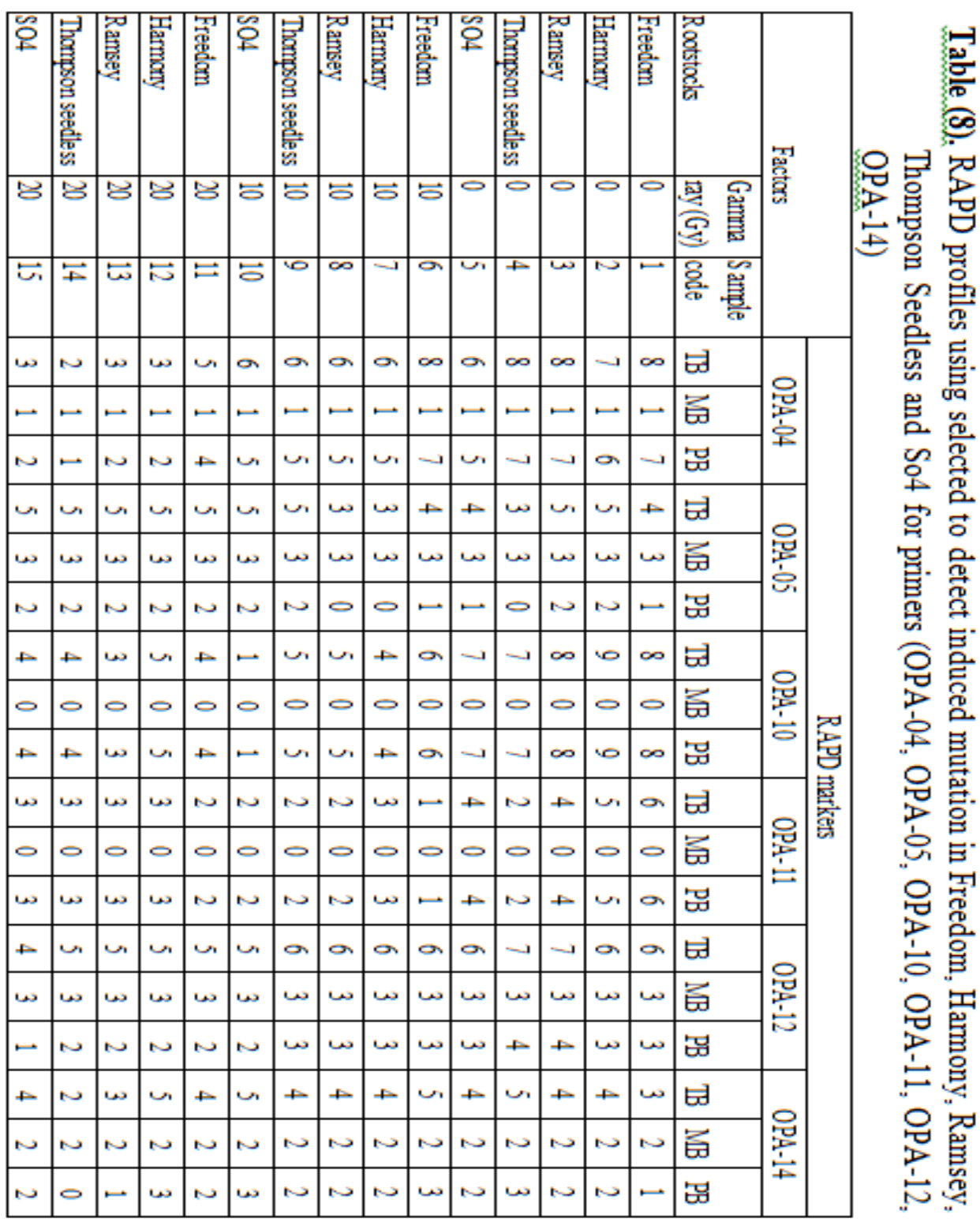




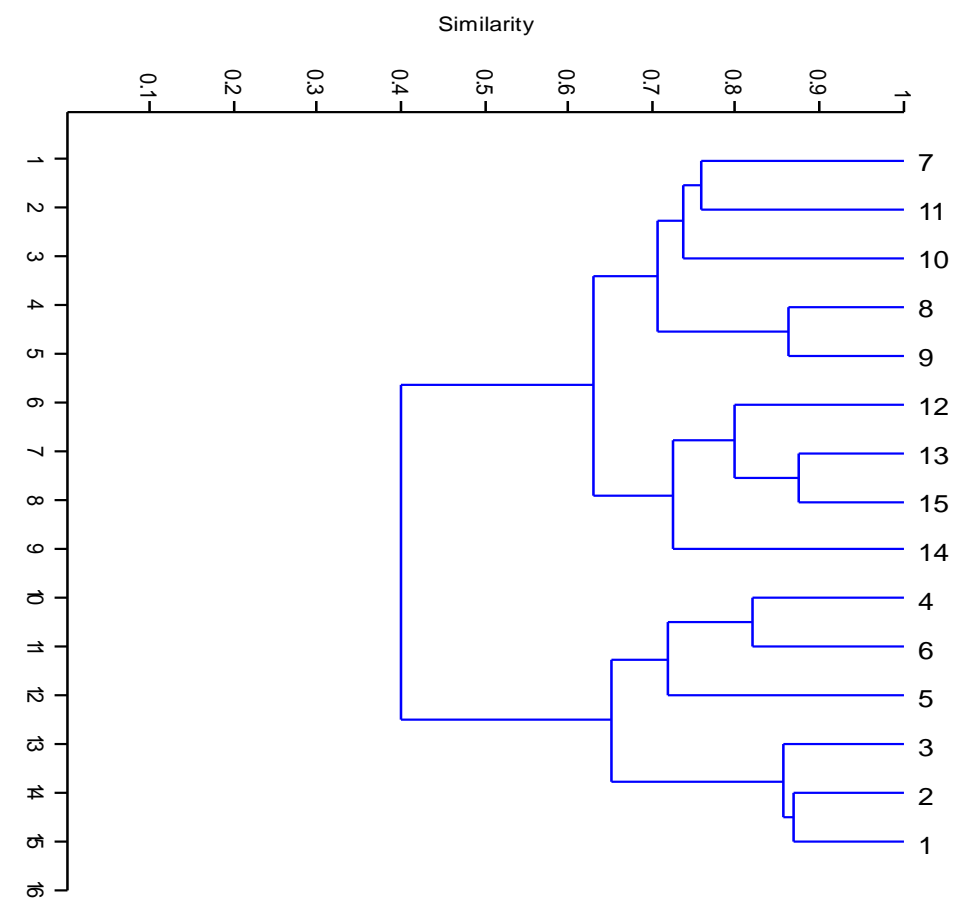

. Figure (3). Genetic relaetness among grapevine rootstocks treated with gamma rays

Dendrogram showing the genetic relatedness of five grapevine rootstocks along with a commercial scion Thompson seedless cultivar treated with gamma rays through six RAPD primers. 1=cont Freedom $2=$ cont Harmony $3=$ cont Ramsey 4= cont Thompson seedless 5= cont So4 6=10 GY Freedom 7=10GY Harmony 8=10GY Ramsey 9=10GY Thompson seedless 10=10GY SO4 11=20GY Freedom 12= 20GY Harmony 13=20GY Ramsey 14=20Gy Thompson seedless $15=20 \mathrm{GY}$ So4.

\section{CONCLUSION}

Radiation is one of the most successful mutagens used in plant breeding programs. It has the ability to change the plant genome and increase genetic variability in a short time in a safe and conclusive manner. Hence, the plant breeder can make the selections with desirable traits. This might be helpful in grapevine rootstocks for selecting genotypes with high tolerance to biotic and abiotic stress. In the present study, mutations were induced through gamma irradiation (10 and $20 \mathrm{~Gy}$ ) in five grapevine genotypes including commercial variety Thompson seedless. These mutations were confirmed by morphological 


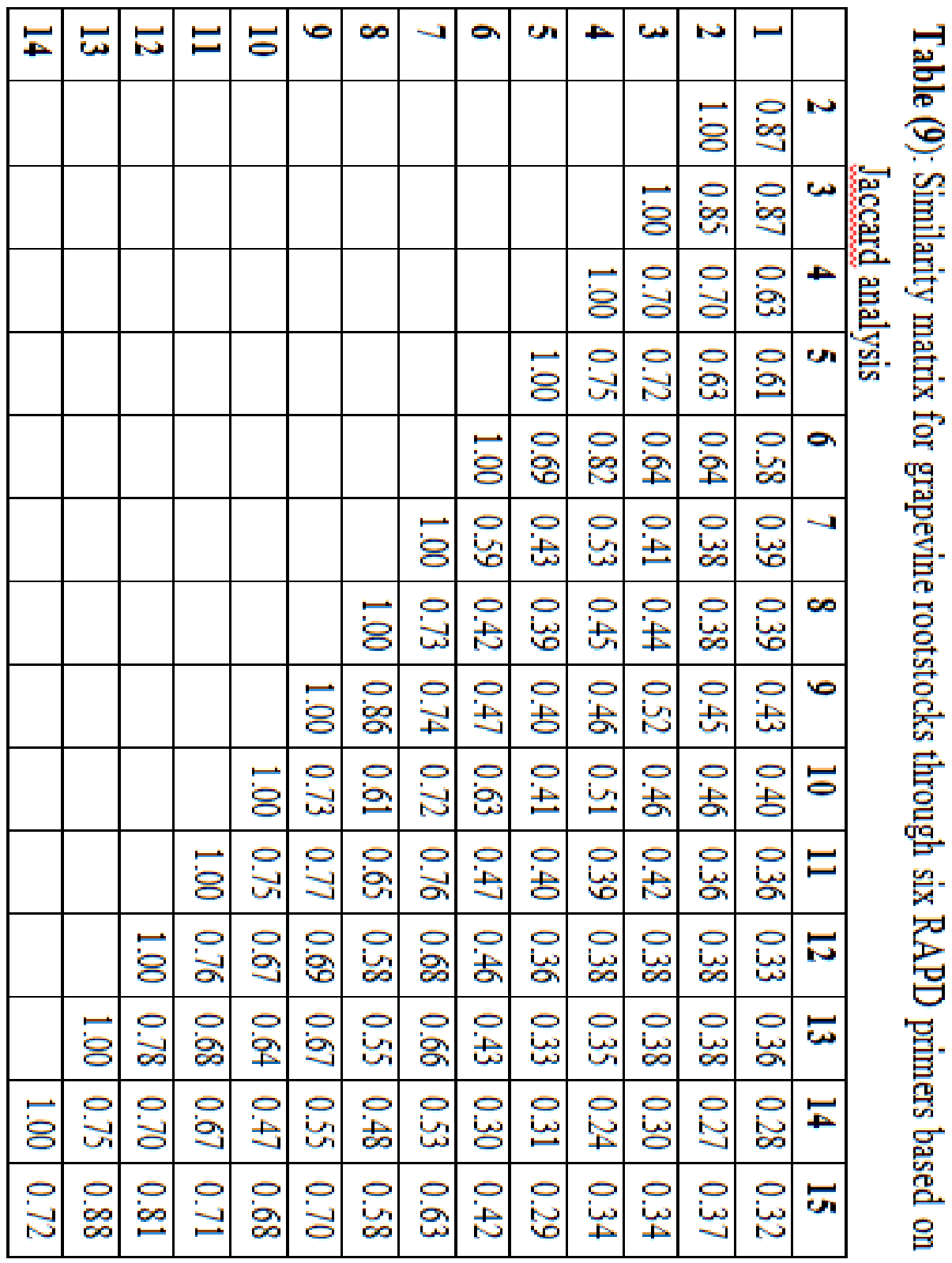


and genetic markers (RAPD). The use of RAPD markers has been of great importance in the characterization and identification of genetic variation and relationships between different genotypes and radiation treatments with high accuracy. The developed mutant materials will be subjected to distinct, uniformity and stability trials for resistance to abiotic stress, in particularly drought and salinity for development of new grapevine rootstocks adapted for Egyptian condition.

\section{REFERENCES}

Beyaz, R.; Yildiz, Ç.; Cengiz, S.; Yildiz, Ç.; Kusvuram, S. and M. Yildiz (2016). Physiological responses of the M1 sainfoin (Onobrychis viciifolia Scop.) plants to gamma radiation. Applied Radiation and Isotopes, 118:73-79.

Buitkamp, J.; Zischler, H.; Epplen, J. T. and H. Geldermann (1991). DNA Fingerprinting in Cattle Using Oligonucleotide Probes. Animal Genetics, 22: 137-146.

Buscher, N.; E. Zyprian and R. Blaiach (1993). Identification of grapevine cultivars by DNA analysis. Vitis, 25-35.

Coban, H.; Kara, S. and E. Ilter (2002). Investigation on Radiosensitivity of some grape varieties. Pakistan Journal of Biological Sciences, 5: 601603.

Dardeniz, A. and S. Tayyer (2005). An investigation on the bud-break and growth of cuttings of $420 \mathrm{~A}$ and 5 BB American vine rootstocks irradiated with different gamma doses. J. Cent. Eur. Agric., 6(2): 173-17

Donini, B. (1993). Mutation breeding programs for the genetic improvement of vegetative propagated plants in 1taly. IAEA-SM-311/152, 15: 247-248.

Doyle J. J. and J. L. Doyle (1990). A rapid DNA isolation procedure for small quantities of fresh leaf tissue. Focus, 12: 13-15.

Duncan, B. D. (1955). Multiple range and multiple F-test. Biometrics J., 11:142.

Esmault, M. A. and C. Chenal (2010). Ionizing radiation advances in plant response. Environ mental and Experimental Botany, 68: 231- 237.

FAO, (2017). Food and Agriculture Organization. http://faostate.fao.org.

Hearn, C. J. (2001). Development of seedless grapefruit cultivars through budwood irradiation. Hortscience, 20: 84.

Huglin, P. (1958). Recherche's sur les bourgeons de la vigne, Initiation florale et development vegetative. Annals de L'Amelioration de plantes, Paris, 7:11. 
Klu, G. Y. P. and A. M. von Haarlent (2000). Opt Orthasiphon imization of mutant recovery from plants obtained gamma radiated seeds of winged bean (Psophocarpus tetragolobus). J. Appied Sci. Tech., 5: 56-62.

Kiong, A.; A. Lingpick; S. H. Grace Lai and A. R. Harun (2008). Physiological responses of stamineus plantlets to gamma irradiation. American Eurasian Journal of Sustainable Agriculture, (2)149: 135.

Lanying, Z.; W. Yongqing and Z. Li (2008). Genetic diversity and relationship of Rhododendron species based on RAPD Analysis. Am.-Eur. J. Agr. Environ. Sci., 3(4): 626-631.

Preussa, S. B. and A. B. Brittz (2003). A DNA-Damage-Induced Cell Cycle Checkpoint in Arabidopsis. Genetics 164: 323-334

Rabie, K. A. E.; S. A. M. Shehata, and M. A. Bandok (1996). Hormone imbalance, germination, growth and pod shedding of Faba beans as affected by gamma irradiation. Annals of Agricultural Science, 41:551556.

Saiful Islam, A. F. M.; Muzahedul Islam, M. and M. Mehedi Hasan (2015). Effect of gamma irradiation doses on morphological and biochemical attributes of grape saplings. Agri. Sci., 6:505-512.

Shah, M. A; Mir, S. A.; S. I A. Pala (2008). Enhancing food safety and stability through irraddiation: A REVIEW. J Microbiol Biotech Food Sci., 3 (5): 371-378

SPSS (2016). SPSS for Windows SChicago, IL SPSS®. Computer Software 18.00,. SPSS Inc., Headquarters. Wacker Drive, Chicago, Illinois 60606, USA., pp: 233.

Surakshitha, N. C.; Soorianathasundaram, K. and N. M. Ganesan (2017). Determination of mutagenic sensitivity of hard wood cuttings of grapes 'Red Globe' and 'Muscat' (Vitis vinifera L.) to gamma rays. Sci. Hort., 226:152-156.

Tayyer, S.; Dardeniz, A. and S. Oldacay ( 2003). Effects of different gamma radiation doses on the shooting and growing of the one-eyed scions of the canes of Amasya grape variety. J. Applied sciences, 3(3):185-188.

Vivier, M. A. and I. S. Pretorius (2002). Genetically tailored grapevines for the wine industry. Trends Biotechnol., 20: 472-478. 


\section{التنوع الوراثي والعلاقات بين طفرات أصول العنب

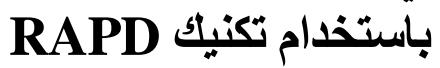

محمد عبده زيان 1، علي رمضان ال شريف11، عائشة صالح عبد الرحمن جاسر²، أسماء

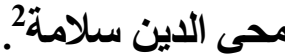
1 ـقشم الفاكهة، كلية الزر اعةدة، جامعة كفر الثيخ، مصر.

2 ـقسم بحوث زر اعة العنب، معهد بحوث البسـاتين، مركز البحوث الزئه الزر اعيـة، الجيزة،

استخدام الاشعاع في احداث طفرات يعتبر وسيله مهمه في دمج صفات ور اثيـة ذات اته

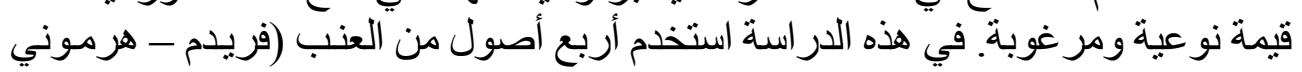

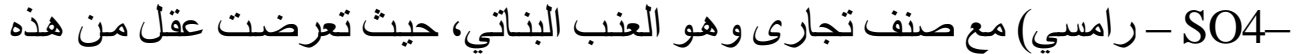

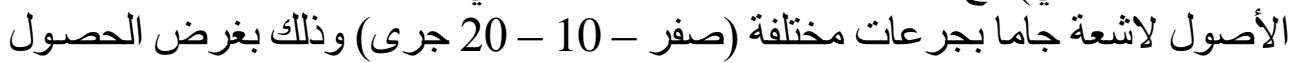
على طفرات ذات قيمة اقتصادية مر غوبة لتر اكيب العنب الور اثية.

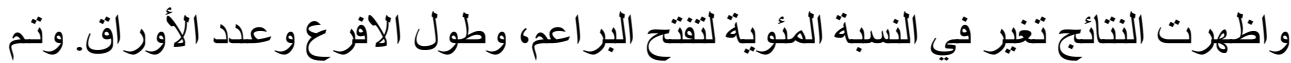

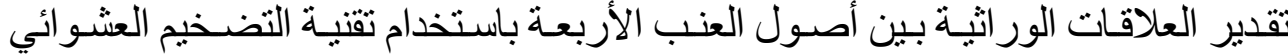
للحمض النووي RAPD باستخدام تفاعل PCR. و اتضـح من اختبار

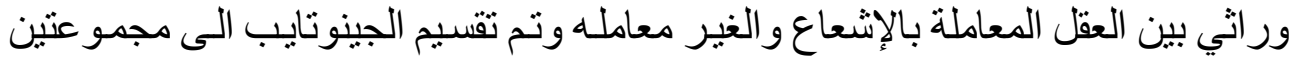

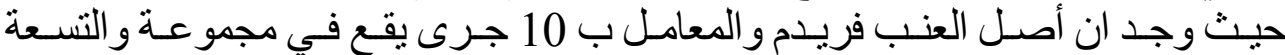

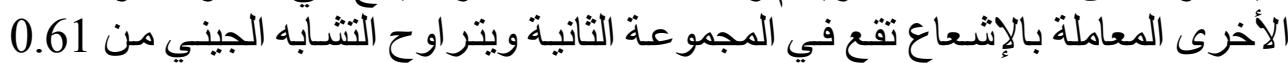

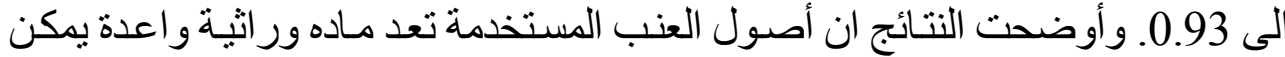

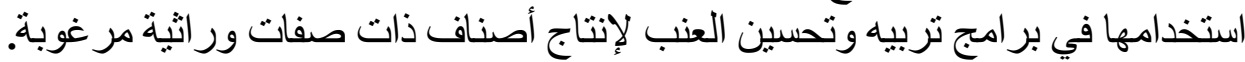

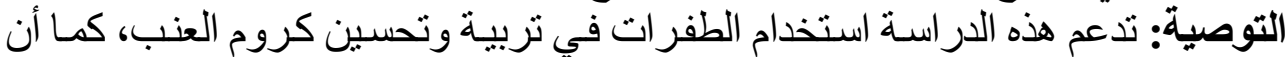

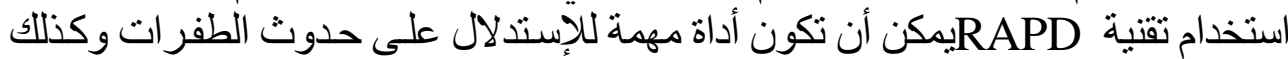
الاستدلال على التتوع الوراثي خلال التر اكيب الور اثية لكروم العنب. 